\title{
« Turkestanskoe bjuro Kominterna (osen' 1920 - osen' 1921) », Vostok, 1 (1999), pp. 59-77. [The Turkestan Bureau of the Comintern]
}

\section{Reinhard Eisener}

\section{(2) OpenEdition}

1 Journals

\section{Édition électronique}

URL : http://journals.openedition.org/abstractairanica/36672

DOI : 10.4000/abstractairanica.36672

ISSN : 1961-960X

Éditeur :

CNRS (UMR 7528 Mondes iraniens et indiens), Éditions de l'IFRI

\section{Édition imprimée}

Date de publication : 15 mai 2001

ISSN : 0240-8910

\section{Référence électronique}

Reinhard Eisener, « « Turkestanskoe bjuro Kominterna (osen' 1920 - osen' 1921) », Vostok, 1 (1999), pp. 59-77. [The Turkestan Bureau of the Comintern] », Abstracta Iranica [En ligne], Volume 22 | 2001, document 285, mis en ligne le 15 février 2010, consulté le 13 octobre 2020. URL : http:// journals.openedition.org/abstractairanica/36672 ; DOI : https://doi.org/10.4000/abstractairanica. 36672

Ce document a été généré automatiquement le 13 octobre 2020.

Tous droits réservés 


\title{
« Turkestanskoe bjuro Kominterna (osen' 1920 - osen' 1921) », Vostok, 1 (1999), pp. 59-77. [The Turkestan Bureau of the Comintern]
}

\author{
Reinhard Eisener
}

Far from providing a systematic description of the short-lived Turkestan Bureau of the Comintern in Tashkent, its organization, functions and activities, this article basically is a presentation of some findings about this institution in the fond 544 (content?) of the former Central Party Archive in Moscow. Gilensen's interpretations are partly rather speculative, because it is evident that there is a lack of sufficient knowledge about the general historical situation, related circumstances (the Anglo-Soviet negotiations), or the role of and the interrelations with other Moscow institutions in Turkestan, e.g. Turkkomissija, Turkbjuro $C K$; that the Turkestan bureau of the Comintern followed in the footsteps of Sovinterprop (the Council of International Propaganda) is not even mentioned. Nevertheless, these document findings deserve some interest. They show rather clearly that this undertaking of the Comintern, besides causing some internal trouble, was almost totally inefficient, and that lots of money was wasted on more or less doubtful revolutionary efforts and figures.

\section{INDEX}

Thèmes : 4.6. Histoire de l'Asie centrale et Caucase (à partir de 1917) 


\section{AUTEURS}

REINHARD EISENER

Berlin (Allemagne) 